\title{
Expanding Worlds: Neo-Victorianism, Fan Fiction, and the Death of the Author
}

\author{
Jan-Erik Ella
}

"[W]e know that to give writing its future, it is necessary to overthrow the myth: the birth of the reader must be at the cost of the death of the Author."

(Roland Barthes 1967/1977, 148)

The late 1960s bore witness to a pivotal change in the way literary production and reception were perceived. When Roland Barthes declared traditional notions of authorial control to be null and void, the supposedly one-directional relationship between author and reader had already been challenged. ${ }^{1}$ Even before Roland Barthes published his seminal essay "The Death of the Author" in 1967, the notion of a particular work of fiction being the product of a single, creative mind (who also served as the sole arbiter of intended meaning within a text) had started to crumble. In fact, postmodern sentiments had emerged over an extended period of time, and Barthes's image of the 'Author' looked more like an overblown parody than a concept that was actually embraced by anyone. Accordingly, some of Barthes's critics accused him of using a "straw-man strategy" (Norris 1994, 404), making his own hypothesis look more plausible by contrast. ${ }^{2}$ In many ways, the

1 Or more precisely, this time period marked a gradual return to a conception of literary production and reception that had persisted throughout most of human history and only became obfuscated by notions of originality and intellectual property.

2 Barthes most certainly uses exaggeration in his essay; yet I would argue that he employs it to highlight particular aspects of the 'Author' as a concept, creating an image that comes close to being a parody, yet in fact only serves to pinpoint specific problems. 
reader Barthes envisioned had already emerged, and the boundaries between artist and audience, producer and consumer grew increasingly blurry. Lev Grossman considers the year 1966 to be the starting point for this new (or old) approach to storytelling:

First, Jean Rhys published Wide Sargasso Sea, her feverish reimagining of the story of Bertha Mason, Mr. Rochester's first wife, from Charlotte Brontë's Jane Eyre. That same year saw the first performance [...] of Tom Stoppard's Rosencrantz, and Guildenstern Are Dead, which expands upon the brief lives of two hapless supernumeraries from Shakespeare's Hamlet. The third thing that happened that year was the premiere [...] of Star Trek[,] one of the first shows to attract not only an audience but a fan community, [who] began publishing and circulating mimeographed zines [...] containing along with articles, essays and editorials, and fan art - fanfiction: original, unsanctioned stories about the characters from the show, set in the world of the show. (2013, xi)

Such unofficially - or, in the case of neo-Victorian novels like Wide Sargasso Sea, officially - published expansions of pre-existing fictional worlds allow their creators to explore angles that have not been covered by the canonical texts they are adapting. Accordingly, they can give a voice to marginalized minorities or individuals, explore non-normative sexuality or gender, or touch upon conflicts that have not been properly addressed in the source material. In short: they explore the uncharted territory beyond the narrowly defined borders of mainstream culture, constituting what Abigail Derecho refers to as "archontic literature" (2006, 61). She borrowed the term "from Jacques Derrida's definition of archives as ever expanding and never completely closed" (61), defining pastiches or fan fiction as additions to the literary archive of their respective parent texts. "Rhys' addition to the [Jane Eyre] archive takes the older contents of the archive - Jane Eyre's goodness, innocence, and heroine status, Rochester's position as a tormented but deserving hero, and Bertha's role as the unreasoning animalistic shadow villainess - and changes them by refracting the elements through a mirror of her own design" (Derecho 70).

Although the concept of intellectual property and the idea of the author as the sole creator of a fictional text persist to this day, more and more people - both professional authors and amateur writers - come to embrace a more collective approach to storytelling. Writers deliberately seize upon fictional settings or characters that have been created by others, not in order to plagiarize but to expand upon the source material, adding new voices to a polyphony of different readings. This trend has only increased since the early 1990s when the spread of the internet gradually allowed more and more people to exchange and share their ideas.

In this essay, I will look at two distinct phenomena that are closely tied to this post-modern awareness of what Julia Kristeva calls intertextuality: fan fiction and neo-Victorianism, both of which took their current shape in the late 1960s and 
experienced a veritable boom since the late 1980s. This essay attempts a look at what both of these can achieve. In many ways, it is a defence of a literary approach that is still far too often dismissed as a stale and derivative imitation of supposedly greater artists. I will show how expanding upon pre-existing fictional worlds can add to our understanding of a parent text by drawing attention to aspects of plot or character that have been marginalized or glossed over, thus engaging in an active dialogue with a literary predecessor. Even more than that, such an approach to storytelling can help us gain a better understanding of the cultural content embedded within a certain text, often revealing unconscious material associated with the era in which it was originally conceived and showing its link to controversial present-day issues.

But first it will be necessary to answer two important questions: What defines fan fiction and neo-Victorianism respectively? What distinguishes them from other forms of writing? In the case of fan fiction, the answer seems to be fairly obvious yet matters are not quite as clear-cut as they might appear at first glance. The distinction between a fan writer and a 'genuine' author may seem obvious, but as Anne Jamison points out: "Reworking an existing story, telling tales of heroes already known to be heroic, was the model of authorship until very recently" (2013, 18; emphasis in the original). Greek dramatists seized upon a well-known body of myths, re-using plots and characters to give a new spin to an old tale: Euripides's Medea, for example, supplies its source material with a new ending that turns the titular character into a deliberate filicide, whereas older versions of the myth portrayed her sons' deaths as an accident or held the citizens of Corinth responsible for the deed. Likewise, Shakespeare's Hamlet is most likely based on a source text lost to history and a contemporary dramatic adaptation of the Hamlet story. ${ }^{3}$

Furthermore, if we follow Julia Kristeva's definition of intertextuality, "any text is a mosaic of quotations; any text is the absorption and transformation of another" $(1980,66)$. No literary text exists in isolation, but it is only rendered comprehensible by seizing upon an indeterminate number of intertexts that render it accessible to the reader. That is how certain tropes can be used or subverted. But of course, this relationship between different texts exists regardless of the author's intentions and it does not necessarily take the form of an overt connection between a clearly identifiable parent text and a pastiche, parody, or adaptation. Fan fictions (and commercially produced rewritings) are a special case because they do not merely allude to their literary predecessor, but take place within the same fictional space, employing the same fictional characters. Even in the Victorian period, when the concepts of intellectual ownership and of the author as the sole creator of a work of fiction were most likely at their strongest, forerunners to fan fiction existed: "Fans have been engaging in illicit, unsanctioned interactions with other

3 The so-called Ur-Hamlet was first mentioned in 1589, at least ten years before Shakespeare's version appeared on the London stage. Neither the play itself nor the identity of its author are known any longer, yet its existence is fairly well established (Jenkins 2008, 83). 
people's characters and stories since at least the nineteenth century. Jane Austen's niece once wrote her a letter addressed to Georgiana Darcy. In 1893, no less a fan than J.M. Barrie wrote a story starring Sherlock Holmes and Dr. Watson" (Grossman 2013, xii).

Keeping this in mind, it becomes fairly obvious that the distinction between a 'real' author (who supposedly creates a whole fictional world out of thin air) and a fan (who merely revisits somebody else's intellectual property) does not hold: it is a more or less arbitrary dividing line, based upon fallacious notions of how a literary text is created and what 'genuine' literature ought to look like. As such, the term 'fan fiction' simultaneously challenges and perpetuates the notion of a more or less one-directional author-reader-relationship. On the one hand, it subverts the notion of a passive reader by virtue of the fact that the fans become actively involved with specific fictional universes, creating their own stories and adding their voices to the archive. On the other hand, however, the term clearly holds on to a clear-cut distinction between a fan and a 'real' author. It might be tempting to draw the line between these two according to the degree of professionalism and craftsmanship involved, yet the distinction between fan fiction and 'real' literature cannot necessarily be made simply in terms of quality of writing. While many (if not most) fan creations may indeed lack the literary skill that would make them eligible for commercial publication, some of these texts certainly do qualify as genuine art that can easily live up to the standards of 'serious' literature. Simultaneously, some published texts - including commercially successful ones - may not necessarily rise above even the poorer examples of fan fiction. The example of E.L. James's incredibly successful novel Fiffy Shades of Grey (which started out as a series of fan fiction stories set in Stephenie Meyer's Twilight universe) should serve as sufficient evidence that these boundaries are permeable and that these distinctions only help to communicate a very general idea about how a specific fiction relates to others. For the purpose of this essay, the defining characteristic that distinguishes fan fiction from traditionally published neo-Victorian rewritings is the fact that the former is not distributed for commercial purposes, but only circulated within the fan community. Professionalism is a defining criterion, but only as far as monetary aspects are concerned. Other than that, a neo-Victorian text like The League of Extraordinary Gentlemen could easily be classified as fan fiction, as it so clearly seizes upon pre-existing characters and settings from $19^{\text {th }}$-century literature.

Far from being merely derivative, fan fiction explores pre-existing fictional universes further than the original authors ever did, thus allowing people to develop "a richer understanding of [themselves] and the culture around [them]" by means of their own "folk culture" and their communal efforts to "share and compare value systems by evaluating fictional dramas" (Jenkins 2008, loc. 3923). The same can be said about most neo-Victorian pastiches or rewritings: they are a form of auto-ethnography, tracing the roots of contentious issues within the present cultural climate back to their supposed historical origin. They give a voice to characters who were once silenced, provide perspectives that were once considered 
taboo, and thereby have the potential to transform their readers' perception of the past and present alike. According to Derecho, "the archontic principle seeks to empower and elevate what is subordinate [...]. Fan fiction has a long history of appealing to women and minorities, individuals on the cultural margins who use archontic writing as a means to express not only their narrative creativity, but their criticisms of social and political inequities as well" $(2006,76)$. This observation can most certainly also be applied to neo-Victorian fiction.

But what does the term 'neo-Victorianism' convey? Like 'intertextuality,' it is a term that is often "underdetermined in meaning and overdetermined in figuration," as Graham Allen put it $(2000,2)$. More often than not, it is indiscriminately used to refer to any recently published fictional text set in the Victorian period. Even the online Journal of Neo-Victorian Studies refused to establish a clear-cut definition of the term in its opening issue, going so far as to apply it to fictional texts set during the Regency period or the Edwardian era:

What this introduction will not, indeed cannot pretend to do, then, is to provide the (still) missing definitions or delineate possible generic, chronological, and aesthetic boundaries - objectives which more properly belong to the project ahead. The same refusal of pre-emption also underlies the editorial board's decision to adopt the widest possible interpretation of "neo-Victorian", so as to include the whole of the nineteenth century, its cultural discourses and products, and their abiding legacies, not just within British and British colonial contexts and not necessarily coinciding with Queen Victoria's realm; that is, to interpret neo-Victorianism outside of the limiting nationalistic and temporal identifications that "Victorian", in itself or in conjunction with "neo-", conjures up for some critics. (Kohlke 2008, 2)

Keeping the term's definition as open as possible has its advantages, especially as it allows for a wider range of critical inquiry and promotes the gradual formation of a scholarly consensus. If the boundaries were drawn too tight in advance, important aspects of the phenomenon as such might be missed by researchers. However, a concise definition of what constitutes a neo-Victorian text and - even more importantly - what does not, is clearly desirable. My essay expands upon a definition that has been formulated by Ann Heilmann and Mark Llewellyn: "[T] he 'neoVictorian' is more than historical fiction set in the nineteenth century. To be [considered a part of this genre], texts (literary, filmic, audio/visual) must in some respect be self-consciously engaged with the act of (re)interpretation, (re)discovery, and (re)vision concerning the Victorians" (2010, 4; emphases in the original). This meta-fictional awareness is a crucial part of neo-Victorianism, setting it apart from more conventional historical novels set in the Victorian period. These are best classified as 'pseudo-Victorian,' as they tend to emulate Victorian parent texts without casting a new light upon their subject matter. Although such texts sometimes contain interesting subversions and anachronisms, these tend to be predominantly uninten- 
tional, owing more to a lack of research than to any conscious effort on the part of the authors. These texts do not aim to challenge clichéd Victorian tropes or stereotypical characters, but merely reproduce them to the best of the writers' ability.

To give an example, the difference between Annabella Bloom's pastiche Wuthering Heights: The Wild and Wanton Edition and Peter Carey's novel Jack Maggs should be readily apparent. Jack Maggs is a rewriting of Charles Dickens's Great Expectations, told from a post-colonial vantage point that draws attention to prevalent Victorian prejudices with regard to the penal colonies and their inhabitants. Both the titular protagonist, a stand-in for Dickens's Magwitch, and his young protégé Henry Phipps are portrayed in a fashion that contrasts strongly with the parent text. Whereas Dickens's Magwitch at first appeared as a terrifying figure who embodied every misgiving and prejudice the Victorians had with regard to the inhabitants of their penal colonies, Carey's Jack Maggs appears in a decidedly more positive light. His desire to return to and identify with the land of his birth is portrayed as a tragic flaw, a misjudgment that is embodied in the shape of the unworthy Henry Phipps. The young man is callous and ungrateful and only desires to protect his good name from being associated with a former convict, while disowning his secret benefactor as much as possible. An in-depth analysis of Carey's novel would exceed the scope of this essay, yet, put succinctly, the rewriting directs the readers' attention towards the underlying colonialist ideology embedded in Great Expectations, steering their sympathies more clearly towards the exiled convict rather than his unworthy surrogate son. Thus, Carey criticizes Dickens's portrayal of Magwitch as a quasi-demonic figure and redeems the character by giving him a voice of his own. In short, it is a clever inversion of its parent text that emulates and reconfigures its predecessor.

Annabella Bloom, on the other hand, has reduced Emily Brontë's classic Wuthering Heights to a truncated romance novel interspersed with semi-pornographic effusions. Her version of Cathy describes: "When his arms surround me, I feel his body harden against me, his staff lengthen and press into my belly" (Bloom 2011, 2). Erotica certainly do have their place in the wider realm of fiction, and female desire in particular has been underrepresented in the past. Yet in this particular case, it is perfectly clear that Bloom's re-telling cannot offer any new insights into Brontë's novel. On the contrary, it reduces its source material to a perfunctory romance whose primary function is to provide sexual stimulation. The best that could be said about this novel is that it reclaims female passion, embracing an ethos that stands in marked contrast to the sinner-saint-dichotomy underlying traditional (Victorian) middle-class conceptions of femininity. By portraying the relationship between Catherine and Heathcliff in primarily erotic terms, Bloom defies and challenges the notion of a predominantly passive and subdued female sexuality. It is highly dubitable whether this subversion of Victorian morality is the result of a deliberate engagement with the past, however; it more likely results from an anachronistic projection of contemporary standards upon the past. 
To recapitulate: it is a deliberate engagement with specific historical or cultural blind spots that defines neo-Victorian fiction and distinguishes it from retro-Victorian imitations. This confrontation of the collective Victorian 'Shadow' (in the sense of a Jungian archetype embodying the darker aspects of $19^{\text {th }}$-century culture) is a central element of neo-Victorianism - and it can be found in vastly different texts from many different sub-genres, ranging from graphic novels over crime fiction to 'literary' novels. "The re-presentation of the Victorian era in [neo-Victorian] novels celebrates the potential of the literary text as an act of memory. Its imaginative re-creation stems from a desire to re-member the period as part of $[\ldots]$ our cultural memory, and asserts both continuities and discontinuities between Victorian culture and our own" (Mitchell 2010, 182). In some cases, it might be difficult to distinguish whether a specific text qualifies as pseudo- or as neo-Victorian, yet such a distinction most certainly helps to establish certain generic criteria.

Literary texts that deliberately seize upon preceding fictions need not be mere imitations. They can be valuable expansions of their source material or even engage in a sort of dialogue with their parent text that challenges some of its assumptions. An excellent example of this approach can be found in Alan Moore and Kevin O'Neill's comic book series The League of Extraordinary Gentlemen. First published in 1999 by the independent publisher America's Best Comics, ${ }^{4}$ this series is based upon the premise that any fictional text ever published is actually a factual report. As a result, it takes place in an alternative Victorian age where Count Dracula's invasion of Britain was barely averted, Sherlock Holmes faked his death at the Reichenbach falls, and Martians are invading the planet with gigantic tripods (just to mention a few events). The title The League of Extraordinary Gentlemen evokes a certain Victorian style, yet at the same time links it to contemporary superhero team comics such as DC's Justice League or - in terms of the team members' status as maligned outcasts and social misfits - Marvel's X-Men. In fact, the first two collected volumes of the series can be read as a meta-fictional meditation on the roots of the superhero genre, highlighting its ties to $19^{\text {th }}$-century literature. This is especially apparent in the case of Dr. Jekyll and his monstrous alter ego, Edward Hyde (from Robert Louis Stevenson's novella): Hyde, as the embodiment of the isolated, uninhibited darker side of Dr. Jekyll's original personality, has grown to enormous proportions - a colossal brute that clearly serves as a nod to one of the character's literary descendants, Marvel Comic's Incredible Hulk. ${ }^{5}$ Jekyll/Hyde is but one member of a larger group of protagonists who were created by different authors - like the heroes of the Justice League such as Batman (created by Bob Kane and Bill Finger) and Wonder Woman (originally conceived by the psychologist and

4 America's Best Comics was founded by Alan Moore who has spent his entire life in Great Britain; so it is safe to assume that the title is at least partially ironic.

5 The Hulk's creator, Stan Lee, freely admits to his source of inspiration: "I decided I might as well borrow from Dr. Jekyll and Mr. Hyde [...] - our protagonist would constantly change from his normal identity to his superhuman alter ego and back again" $(1974,75)$. 
writer William Moulton Marston). They are recruited by the British Secret Service and serve as a covert unit charged with protecting the Empire from unusual threats. Like a late Victorian version of the X-Men, they seek to help a world that rejects, fears, or reviles most of them. Moore and O'Neill seized upon a wide range of Victorian literature, ranging from classics to the most obscure 'penny dreadfuls.' In true neo-Victorian fashion, they imbue well-known characters and their original narratives with new layers of meaning. Two protagonists in particular stand in marked contrast to the way they were portrayed in their parent texts - even if they are still clearly identifiable.

Allan Quatermain, originally created by Henry Rider Haggard, would seem to be an ideal candidate for the position of the leader of the Victorian League - at least in the hands of writers who sought to perpetuate the message of the parent texts. ${ }^{6}$ In the parent texts, Quatermain was the quintessential 'great white hunter,' a personification of the British Empire and its colonial politics. Haggard portrayed him as an unbroken hero who carried the torch of civilization into the 'dark continent' of Africa. As the son of a widowed missionary, born and raised abroad, Allan is all but predestined to bear what Rudyard Kipling famously referred to as "The White Man's Burden.” Although Haggard's novels are not entirely unsympathetic with regard to foreign ethnicities, they clearly reflect the dominant views of the Victorian era, including a belief in the superiority of the 'white race' and the perceived need to spread Christianity throughout the world. In Allan Quatermain, it is established that the titular hero died in 1885, ending his heroic career as a champion of the British Empire. However, Alan Moore and Kevin O’Neill resurrect the character by portraying the news of his demise as a deliberate misinformation spread by Quatermain in order to retire. In The League of Extraordinary Gentlemen, the "Empire's favourite son" (Moore and O'Neill 2000, 31) is essentially a broken man, not a shining hero: an opium addict who wastes away in the slums of Egypt (Moore and O'Neill 2000,11ff.). At this point of history, in 1889, the colonialist dream had started to rot from inside, gradually losing its veneer of a noble purpose, and Allan Quatermain reflects this particular change. He is still the personification of the British Empire and its colonial politics, yet now the image is no longer that of a paragon of English virtue. His opium addiction (and his dependency on the Egyptian criminals who provide him with it) may be especially ironic, considering that Britain was openly producing and selling the drug at that time and had even waged two wars in China in order to keep distributing it. A wasted, old man, Quatermain has outlived his glory days, and what remains is a damaged, elderly anti-hero who leaves his retirement only reluctantly.

6 And indeed, the film adaptation of The League of Extraordinary Gentlemen - which was very poorly received by audiences and critics alike - places him in the leadership position, which generates some rather problematic subtexts with regard to the role of the British Empire. The fact that he passes his gun on to Tom Sawyer (a character specifically added for the young male American demographic) only adds to this problem. 
In sharp contrast to this, Mina Murray (formerly Harker) is a considerably more pro-active character than her previous literary incarnation. While she served as little more than a 'damsel in distress' in Bram Stoker's Dracula, she becomes the determined leader of the League of Extraordinary Gentlemen. This may appear like a considerable breach of character at first sight, yet Moore and O'Neill have managed to let the transition appear rather smoothly. In Stoker's novel, Wilhelmina Murray is the epitome of middle-class propriety, a virtuous 'angel in the house.' She serves as a foil to the aristocrat Lucy Westenrae, whose upper-class decadence makes her a perfect victim for the erotic reverse colonization of Count Dracula. Mina, on the other hand, is ultimately saved by her rigid bourgeois morality, for even though she is bitten by the count as well, her reaction is to recoil from herself in horror, crying: "Unclean, unclean!" (Stoker 1897/1994, 339). Her particularly Victorian morality is best exemplified by an early scene in Dracula: after tracking her sleepwalking friend Lucy through town, Mina escorts her back home, slipping her shoes onto the bare feet of her friend:

As we passed along, the gravel hurt my feet, and Lucy noticed me wince. She stopped and wanted to insist upon taking my shoes; but I would not. However, when we got to the pathway outside the churchyard, where there was a puddle of water remaining from the storm, I daubed my feet with mud, using each foot in turn on the other, so that as we went home no one, in case we should meet anyone, should notice my bare feet. (114)

Considering that the Victorian age viewed exposed ankles in the same way contemporary society views exposed female breasts, Mina's actions in this scene might

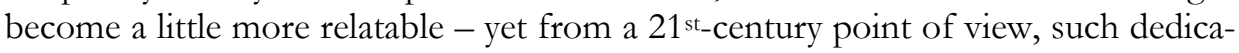
tion to propriety with regard to such a comparatively insignificant detail in the middle of an emergency situation must appear quaint and unintentionally humorous. However, it also bespeaks a considerable strength of character, a strong determination that allows her to survive the hardships to follow.

Dracula concludes with an epilogue set seven years after the plot's resolution. Stoker depicts Mina and Jonathan Harker as a happily married couple, raising a son (named "Quincey" after a friend who died in the final struggle with Count Dracula). But as in the case of Quatermain, Moore and O'Neill change this particular detail by following Victorian morality concerning 'fallen' women to its logical conclusion: the Victorians did not look kindly upon women who had 'lost their honour,' regardless of whether they had been willing accomplices in their 'fall,' or not.7 With this in mind, it seems highly unlikely that Mina would have been able to retain her social status. Accordingly, The League of Extraordinary Gentlemen portrays her as a disgraced divorcee and an outcast from the British middle class. Deeply trau-

7 For example, the titular heroine of Thomas Hardy's Tess of the d'Urbervilles (1891) experienced disgrace and social ostracism on account of having been raped by her lewd cousin. 
matized by Count Dracula's attack, Mina hides her scars - which also serve as a symbol of her fallen state - with a red scarf, simultaneously hiding and drawing attention to her mark of shame. She is highly self-conscious with regard to these marks and cannot conceive that anybody might view her disfigurement as anything other than a signifier of her status as a 'fallen woman' (Moore and O'Neill 2003, 102ff.). However, her exclusion from polite society has only fortified the strength of character already present in Stoker's novel. The divorced Mina Murray is a New Woman who challenges the conventions of her days, as reflected by her reversion to her maiden name, a practice that was highly scandalous in the late 1800s (Moore and O'Neill 2000,12). Society may view her as an outcast, yet she keeps fighting for her home country, becoming the leader and emotional centrepiece of the League of Extraordinary Gentlemen. And unlike several other members of the League, she relies solely on her keen mind and courageous determination. As an unlikely protagonist, she has to struggle against the patriarchal mores of the Victorian world that surrounds her, even in relation to her companions. She stands her ground against the monstrous Edward Hyde (Moore and O'Neill 2000, 138) and even manages to keep the invisible psychopath Hawley Griffin in check. The alpha males Quatermain and Nemo occasionally chafe at the notion of receiving orders from a woman (Moore and O'Neill 2000, 44, 118), yet neither of them openly defies her or undermines her command. In fact, it is her very status as a woman that allows her to unite the group, as all the other members would be sure to challenge and second-guess each other.

The repressed sexuality of Mina's character that was present in Stoker's Dracula is still there, even if it is gradually disappearing due to the experiences she had to go through: when the League visits a girls' school run by a character who originated in Victorian pornography, ${ }^{8}$ Mina coldly refuses the headmistress's job offer (Moore and O'Neill 2000, 49), communicating her disdain for the flagellant with a middle-class haughtiness that is reflected by her facial expression. She decidedly breaks with Victorian morality, however, when she initiates the seduction of Allan Quatermain at a later point of the series, explicitly stating that her expulsion from polite society should suffice to render such decorum superfluous: "Allan, you are dead, while I am divorced, disgraced and disregarded by the world. Could anything make us more wrong, do you suppose?" (Moore and O'Neill 2003, 97; emphases in the original). This determination to make the best of a wretched situation is very much in keeping with Stoker's original depiction of the character, who used the mental link provided by Count Dracula's corruption to help her companions track down and slay the vampire.

8 Rosa Coote "first appeared as the supposed author and narrator of Dugdale's The Convent School, or Early Experiences of a Young Flaggelant (1876), a pornographic novel about flagellation, especially with birch wands" (Nevins 2003, 53). 
Nonetheless, Mina Murray was transformed from the very stereotype of a demure Victorian middle-class woman into a self-confident (proto-)feminist, simply by following the source material to its logical conclusion. This character (along with the rest of the protagonists and the setting as such) is a perfect example of what both neo-Victorian pastiches and fan fiction can aspire to: providing voices to underrepresented minorities, re-evaluating ideological discourses hidden within well-known texts, and uncovering the shadows that lurk within our collective cultural unconscious. To conclude: both fan fiction and neo-Victorian fiction have the potential to add new, formerly marginalized, oppressed, or omitted perspectives to the Derridean archives of their parent texts. By doing so, they contribute to a collective auto-ethnographic memory work that allows writers and readers alike to approach abject material buried within a nation's cultural history. Far from being merely derivative, many such rewritings allow for a better understanding of both the past and - even more importantly - the present. Contemporary society's enormous interest in the abject sides of Victorian culture revolves less around a desire to push the Victorians off their pedestal and has more to do with finding the origin of our own society's conflict zones, regardless of whether they revolve around gender, politics, sex, or some other aspect.

\section{Works Cited}

\section{Primary Sources}

Bloom, Annabella, and Emily Brontë. Wuthering Heights: The Wild and Wanton Edition. Avon, MA: Adams Media Corporation, 2011.

Carey, Peter. Jack. Maggs. London: Faber \& Faber, 1997.

Dickens, Charles. Great Expectations. 1861. London: Penguin Books, 1994.

Euripides. Medea. Ditzingen: Reclam, 1972.

Haggard, Henry Rider. King Solomon's Mines. 1885. London: Penguin Books, 2011.

---. Allan Quatermain. 1887. Public Domain Books, 2004. Kindle file.

Hardy, Thomas. Tess of the d'Urbervilles. 1891. Public Domain Books, 2008. Kindle file.

Kipling, Rudyard. “The White Man’s Burden.” 1899. Web. 3 March 2014.

Moore, Alan, and Kevin O' Neill. The League of Extraordinary Gentlemen. Vol. 1. La Jolla, CA: America's Best Comics, 2000.

---. The League of Extraordinary Gentlemen. Vol. 2. La Jolla, CA: America's Best Comics, 2003.

Stoker, Bram. Dracula. 1897. London: Penguin Books, 1994. 


\section{Secondary Sources}

Allen, Graham. Intertextuality. New York: Routledge, 2000.

Barthes, Roland. "The Death of the Author." 1967. Image, Music, Text. Essays selected and transl. by Stephen Heath. London: Fontana Press, 1977. 142-149.

Derecho, Abigail. "Archontic Literature: A Definition, a History, and Several Theories of Fan Fiction." Fan Fiction and Fan Communities in the Age of the Internet. Ed. Karen Hellekson and Kristina Busse. Jefferson, NC: McFarland \& Company, 2006. 61-78.

Grossman, Lev. Foreword. Fic - Why Fanfiction Is Taking over the World. Anne Jamison. Dallas, TX: BenBella Books, 2013. 3-24.

Heilmann, Ann, and Mark Llewellyn. Neo-Victorianism: The Victorians in the TwentyFirst Century, 1999-2009. New York: Palgrave Macmillan, 2010.

Jamison, Anne. Fic - Why Fanfiction Is Taking over the World. Dallas, TX: BenBella Books, 2013.

Jenkins, Henry. Convergence Culture: Where Old and New Media Collide. 2006. New York: New York UP, 2008. Kindle file.

Kohlke, Marie-Luise. "Speculations in and on the Neo-Victorian Encounter." NeoVictorian Studies 1.1 (2008). Web. 8 March 2014.

Kristeva, Julia. Desire in Language: A Semiotic Approach to Literature and Art. New York: Columbia UP, 1980.

Lee, Stan. Origins of Marvel Comics. New York: Simon \& Schuster, 1974.

Mitchell, Kate. History and Cultural Memory in Neo-Victorian Fiction: Victorian Afterimages. New York: Palgrave Macmillan, 2010.

Nevins, Jess. Heroes and Monsters: The Unofficial Companion to The League of Extraordinary Gentlemen.' Los Angeles, CA: Comicraft, 2003.

Norris, Christopher. "On the Discrimination of Discourse Theories." REAL: Yearbook of Research in English and American Literature. Vol. 10: Aesthetics and Contemporary Discourse. Tübingen: Gunter Narr Verlag, 1994. 355-423. 